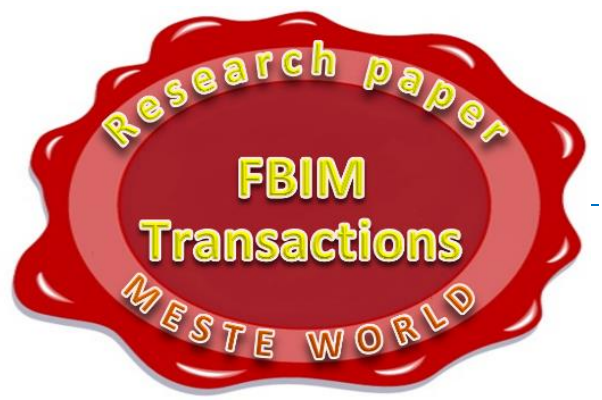

\title{
PROCESNI MENADŽMENT KAO SREDSTVO UNAPRJEĐENJA OBUKE NA PRIMJERU PROIZVODNE TVRTKE
}

\section{PROCESS MANAGEMENT AS A TOOL FOR TRAINING IMPROVEMENT ON THE CASE OF PRODUCTION COMPANY}

\section{Mario Bogdanović}

Istarsko Veleučilište u Puli - Universita Istriana di science applicate Pola, Pula, Hrvatska

\section{Dino Baćac}

Carel Adriatic d.o.o., Labin, Hrvatska

CMESTE

JEL kategorija rada: M21, M53

\section{Apstrakt}

Rad prikazuje metodologiju za unaprjeđenje procesa obuke pomoću procesnog menadžmenta $i$ sustavnog pristupa obuci na primjeru proizvodne tvrtke. Eksplicira se unaprjeđenje trenažnog procesa na sustavan način. Konkretno, identificiran je i prikazan postojeći proces obuke (BPMN grafičkim jezikom), provedena je analiza njegove primjerenosti/djelotvornosti (iskustveno, mjerom reklamacija kupaca i anketnom metodom), te su navedene potporne metode za operativni nadzor i kontrolu novog procesa obuke. Ponuđena metodologija za unaprjeđenje trenažnog procesa može biti primjenjiva $u$ svim tvrtkama koje se susreću s problemom stalnog procesa obuke novih zaposlenika. Uz pomoć procesnog rješenja rješavanjem triju istraživačkih problema potvrđene su postavljene hipoteze: a) razina reklamacija kupaca, obučenost i zadovoljstvo nakon trenažnog procesa nije optimalna; b) proces obuke preoblikovan je sukladno uočenim slabostima postojećeg procesa obuke $i$ sukladno sustavnom pristupu obuci; c) potpora novom procesnom modelu obuke su novi operativni sustavi evidencije, evaluacije $i$ kontrole. Na ovakav način modelirani su i ciljni ishodi obuke (visoka kvaliteta osposobljenosti novih zaposlenika u smislu brzine $i$ kvalitete radnog učinka) čime su stvorene pretpostavke za unaprjeđenje djelotvornosti proizvodnih zaposlenika i proizvodne tvrtke.

Ključne riječi: procesni menadžment, obuka, sustavni pristup obuci, modeliranje poslovnih procesa, unaprjeđenje procesnog modela obuke

Adresa autora zaduženog za korespodenciju Mario Bogdanović

莑; mbogdan2011@gmail.com

\section{Abstract}

This article presents a methodology for training process improvement using process 
management and a systemic approach to training on the production company example. There is explicated the training process improvement systematically. Concretely, there is identified and presented existing training process (by BPMN graphic language), it is analyzed its appropriateness/efficacy (by experience, customer complaints, and questionnaire method), also are explained supportive measures for operative monitoring and new training process control. Offered methodology for training process improvement can be used in all companies where continuous training processes for new employees are needed. Using process solution this study resolved three research problems and validated three hypotheses: a) customer complaint level, skill level, and satisfaction after training process was not optimal; b) training process is redesigned according to defined weaknesses of the existing training process and according to systemic training approach; c) supporting tools to the new training process are new operative systems of evidence, evaluation, and control. In such a manner it is created a model with training target outcomes (high quality of skills after training process in sense of speed and quality of working performance) by which are generated the presumptions for efficacy improvement on the level of production workers and a production company.

Keywords: process management, training, systemic approach to training, business process modeling, improvement of the training process model

\section{UVOD}

Smisao postojanja proizvodne/profitne organizacije ogleda se u njezinoj djelotvornosti, za čime postoji stalna organizacijska potreba. Svaka organizacija želi unaprijediti svoje poslovanje što postiže unaprjeđenjem raznolikih segmenata poslovanja. U poslovanju moguća su različita unaprjeđenja (smanjenje ulaganja i povećanje učinaka), uobičajeno se primjenjuju tehničkotehnološka, ekonomska, bihevioralna, procesna, socijalna/neekonomska i ostala unaprjeđenja. Procesnim unaprjeđenjima bavi se disciplina procesnog menadžmenta. Za unaprjeđenje pojedinog poslovnog procesa osim znanja procesnog menadžmenta, potrebno je i poznavanje procesa koji se želi unaprijediti. $U$ ovom radu riječ je o trenažnom procesu/procesu obuke čije unaprjeđenje se tretira $u$ metodološkom okviru sustavnog pristupa obuci.

\subsection{Procesni menadžment u funkciji unaprjeđenja poslovanja}

Svaka organizacija sustav je koji se sastoji od brojnih procesa (pojednostavljeno rečeno poslova koje treba obaviti). Sam proces se može definirati kao „skup logički povezanih zadataka koji se izvršavaju s ciljem ostvarenja željenog poslovnog ishoda" (Fabac, 2017., str. 22).

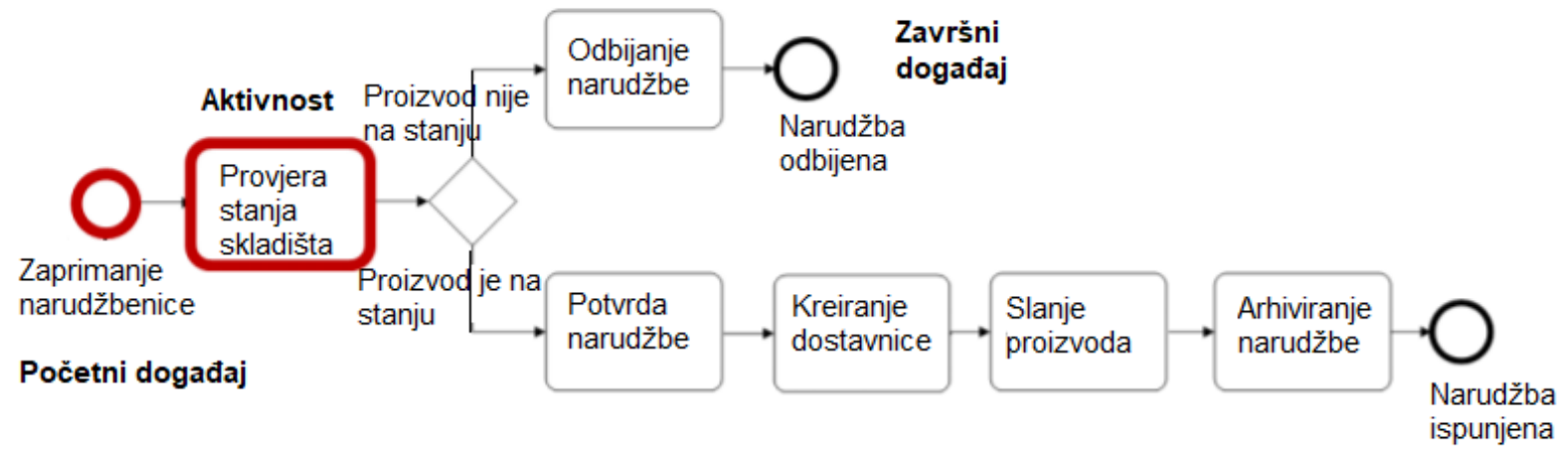

\section{Slika 1. Proces narudžbe u grafičkom jeziku BPMN}

Izvor: Dumas, La Rosa, Mendling i Reijers, (2013., str. 71).

Procesi se identificiraju radi lakšeg sagledavanja svih elemenata procesa i mogućnosti njegovog upravljanja (unaprjeđenja), a modeliraju se i zorno prikazuju upotrebom nekog grafičkog jezika, uobičajeno je korištenje grafičkog jezika BPMN (engl. Business Process Management Notation)
(Martinek, 2018.; Brumec\&Brumec, 2018.; Dumas, La Rosa, Mendling, Reijers, 2013.; Brumec, 2011.). Na slici 1. prikazan je karakterističan jednostavan proces narudžbe putem grafičkog jezika BPMN. 
Praksa procesnog menadžmenta, utemeljena na procesnom razmišljanju i na procesno orijentiranom organizacijskom obliku, ,renesansa“ je modernog poslovanja za koji se koristi termin procesni pristup organizaciji. Međutim, navedena „renesansa" procesnog organizacijskog pristupa nije vođena samo tehnološkim već i društvenoekonomskim inovacijama. Poslovni procesi sve više se smatraju najvrjednijom imovinom u današnjem poslovanju (procesi su ti koji stvaraju stvarne rezultate) pri čemu se njihova vrijednost ne ogleda samo u njihovu izvršavanju, već i u sposobnosti upravljanja njima (identifikaciji/modeliranju, analizi, preoblikovanju, implementaciji, nadzoru i kontroli). Simboli kvalitete poput ISO standarda, modela izvrsnosti EFQM i nagrade Malcom Baladrige u SAD-u, u opsegu vrednovanja izričito uključuju kvalitetu poslovnih procesa. Procesi su važni i u nekim metodologijama unaprjeđivanja poslovanja koji se trenutno primjenjuju, poput samoprocjene utemeljene na kriterijima modela poslovne izvrsnosti, šest sigma inicijative, reinžinjeringa poslovnih procesa ili procesnog menadžmenta. Općenito, posljednjih godina mnoge organizacije provode samoprocjenu vlastitih procesa utemeljenu na kriterijima različitih nagrada za kvalitetu (Vukšić, Hernaus i Kovačič, 2008., str. 42).

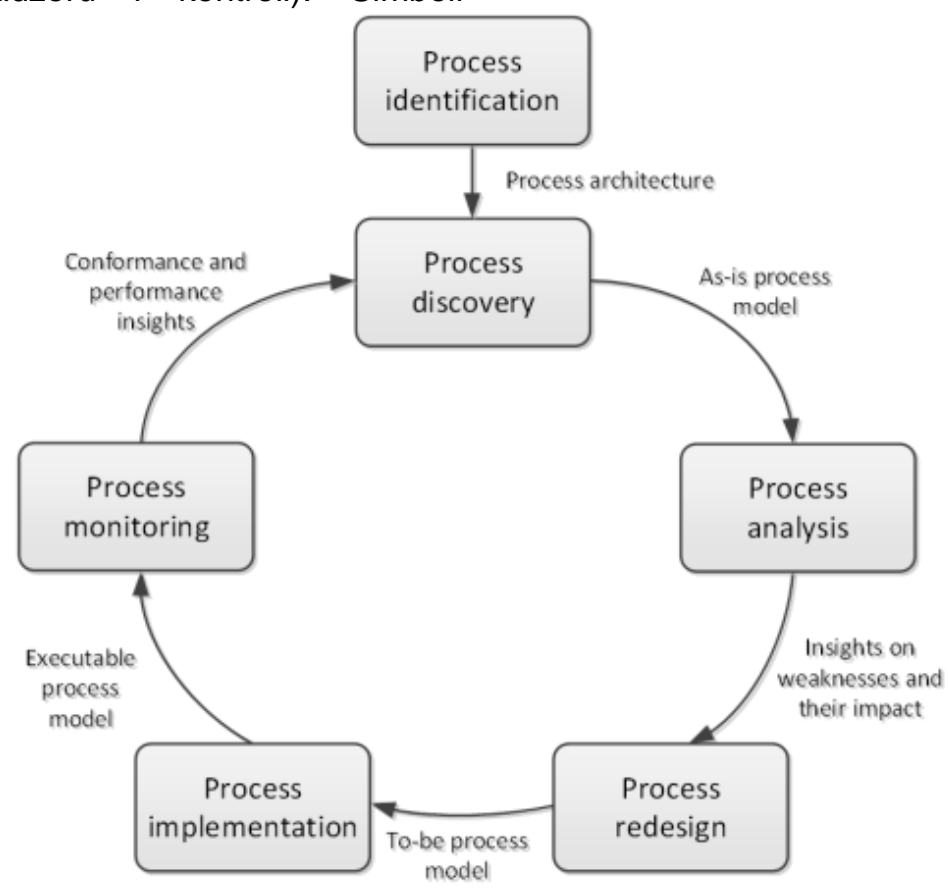

Slika 2. Ciklus procesnog menadžmenta s fazama

Izvor: Dumas, La Rosa, Mendling i Reijers, (2013., str. 21).

Procesni menadžment može se smatrati kontinuiranim ciklusom koji se sastoji od nekoliko faza (Dumas, La Rosa, Mendling i Reijers, 2013., str. 21-22 (Slika 2.):

- Proces identifikacije (engl. Process identification). Problem je postavljen, proces koji rješava problem je identificiran. Rezultat ove faze je procesna arhitektura koja osigurava pregled organizacijskih procesa i njihove odnose. Ponekad se u ovoj fazi provodi mjerenje performansi procesa, a ponekad je to $u$ analizi procesa.

- Uviđanje procesa (engl. Process discovery) /Modeliranje procesa (engl. Process modelling /Procesno oblikovanje (engl.
Process design). Bitni proces se dokumentira u obliku nekog procesnog modela obično grafičkim jezikom (npr. BPMN). Rezultat je proces onakav kakav je (engl. As-is process model).

- Analiza procesa (engl. Process analysis). Identificiraju se „slabe karike“ postojećeg procesa, dokumentiraju se i ako je moguće mjere se performanse u kvantitativnim iskazima.

- Preoblikovanje procesa (engl. Process redesign) /Poboljšanje procesa (engl. Process improvement). Identificiraju se promjene koje će riješiti problem. Odvija se paralelno $s$ analizom procesa. Rezultat ove 
faze je proces kakav bi trebao biti (engl. Tobe process model).

- Procesna primjena (engl. Process implementation). Predstavlja promjenu postojećeg procesnog modela novim procesnim modelom. Uključuje upravljanje organizacijskom promjenom i automatizaciju procesa.

- Nadzor i kontrola procesa (engl. Process monitoring and controlling). Kad se preoblikovan model stavi u funkciju treba ga nadzirati i nadgledati jer mogu nastati novi problemi bilo u preoblikovanom ili drugim procesima što zahtjeva ponavljanje ciklusa procesnog menadžmenta.

$\mathrm{Za}$ istraživačke svrhe u ovom radu korištene su sljedeće faze procesnog menadžmenta: a) Identifikacija/modeliranje procesa; b) Analiza procesa; c) Preoblikovanje procesa; d) Nadzor i kontrola procesa, pa navedene faze procesnog menadžmenta ujedno čine i metodologiju po kojoj je provedeno unaprjeđenje poslovnog procesa obuke.

\subsection{Obuka u funkciji unaprjeđenja poslovanja}

$\mathrm{U}$ organizacijskim uvjetima obuka/trening usmjerena je na stjecanje znanja i vještina vezanih za konkretne poslove i/ili radno mjesto. Suštinski je neodvojiva od obrazovanja i razvoja zaposlenika. Smatra se kontinuiranim procesom koji traje za vrijeme rada u određenoj organizaciji te se općenito tretira ključnim čimbenikom koji pomaže organizaciji maksimalno uvećati svoj potencijal. Brojne tvrtke obuku tretiraju kao stratešku funkciju menadžmenta ljudskih resursa (Bogdanović, Durian i Cingula, 2016.).

Proces razvoja zaposlenika započinje orijentacijom (uvođenjem u posao i početnom obukom) te se nastavlja obučavanjem, savjetovanjem, procjenom i motiviranjem zaposlenika (Quible, 2010., str. 163). Na prepoznavanje važnosti obuke posljednjih godina snažno je utjecalo intenziviranje konkurencije i relativni uspjeh organizacija u kojima se značajno naglašava ulaganje u razvoj zaposlenika, a ubrzan tehnološki razvoj i organizacijske promjene doveli su poslodavce do spoznaje da se uspjeh oslanja na vještine i sposobnosti njihovih zaposlenika, stoga su potrebna značajna i kontinuirana ulaganja u obuku i razvoj (Nassazi,
2013., str. 21). Isti autor (Nassazi, 2013.) navodi brojne prednosti koje donosi kvalitetna obuka:

1. Visok moral - zaposlenici koji prolaze obuku povećavaju vlastito samopouzdanje i motivaciju;

2. Niži troškovi proizvodnje - osposobljavanje uklanja rizike jer je obučeno osoblje sposobno za bolju i ekonomičniju upotrebu materijala $i$ opreme čime se smanjuje $i$ izbjegava otpad;

3. Manje otkaza zaposlenika - obuka donosi osjećaj sigurnosti na radnom mjestu što zauzvrat smanjuje odlazak radne snage $\mathrm{i}$ izbjegava se odsutnost zaposlenika (apsentizam);

4. Upravljanje promjenama - obuka pomaže u upravljanju promjenama povećavajući razumijevanje i uključivanje zaposlenika u proces promjena te također pruža vještine i sposobnosti potrebne za prilagodbu novim situacijama;

5. Pružanje priznanja, povećane odgovornosti i mogućnosti povećanja plaća i napredovanja;

6. Pomoć u poboljšanju kvalitete proizvodnje.

Obuka je ujedno jedan od najvažnijih potencijalnih motivatora koji pojedincima i organizacijama može donijeti i kratkoročne i dugoročne koristi. Upravo se nedovoljno ulaganje u obuku i razvoj zaposlenih navodi kao jedan od ključnih razloga gubljenja udjela na tržištu i zaostajanja (Bahtijarević Šiber, 1999). Rizkalla 2014. (prema HR Magazine) navodi da američke tvrtke koje ulažu $\$ 1.500$ i više godišnje na obuku po zaposleniku imaju prosječno $24 \%$ veći profit u odnosu na tvrtke s manjim godišnjim investicijama u obuku. Isti autor navodi i podatke Američkog društva za obuku i razvoj (ASTD - The American Society for Training and Development) koje je na uzorku od 2.500 tvrtki utvrdilo da opsežna obuka: a) ima $218 \%$ veći prihod po zaposleniku u odnosu na tvrtke za manje opsežnom (šturom) obukom; b) ostvaruje $24 \%$ veći profit u odnosu na tvrtke koje investiraju manje u proces obuke; c) stvara $6 \%$ veći povrat na dionice ako je trošak obuke po zaposleniku iznad $\$ 680$ (Rizkalla, 2014.). Navedeni podaci o ulaganjima imaju logiku u činjenici da obrazovanje zaposlenika igra vitalnu ulogu u poboljšanju performansi i povećanju produktivnosti. To zauzvrat dovodi organizacije do boljih pozicija pri suočavanju $s$ konkurencijom $i$ ostanku pri vrhu. Stoga postoji značajna razlika 
između organizacija koje školuju svoje zaposlenike i organizacija koje to ne čine.

Moguće je primijetiti da se kompetencije zaposlenih mijenjaju kroz učinkovite programe obuke. Stoga ne samo da se obukom poboljšava učinkovitost zaposlenika kako bi učinkovito obavljali svoje trenutne poslove, već se i poboljšava znanje, vještine $\mathrm{i}$ odnos radnika pridonoseći tako organizacijskoj uspješnosti (Nassazi, 2013., str. 29). Osim navedenog obuka i trening okolina potiču kreativnije prijedloge od svih članova tima bez straha od ismijavanja ili preranog odbijanja, a jedna kreativna ideja obično pokrene ostale (Whitemore, 2018., str. 164).

Sukladno navedenom dokazano je da se obukom postižu pogodnosti za poboljšanje performansi kako za zaposlenika, tako i za organizaciju pozitivno utječući na rad zaposlenika razvijanjem znanja, vještina, sposobnosti, kreativnosti, kompetencija i ponašanja zaposlenika (socijalni učinak obuke). Organizacije bi stoga trebale imati stalne politike obuke i zadržavanja zaposlenika i na taj način ne čekati pojave nedostataka u kvalifikacijama i performansama, a sve procese koji se tiču kadrova (od planiranja, regrutiranja, profesionalne selekcije, uvođenja u posao, obuke, obrazovanja i razvoja, ocjene i procjene performansi, motivacije, kompenzacija, zaštite zaposlenika, organizacije i informatizacije kadrovske službe) imati identificirane/modelirane procese što je pretpostavka za optimalizaciju (poboljšanje) svih funkcija menadžmenta ljudskih resursa.

Da bi se na organizacijskoj razini mogao implementirati primjeren/poboljšan novi procesni model obuke koji će potencijalno polučiti superiorne rezultate potrebno je postojanje potpornih i kontrolnih sustava (logistička potpora):

a. Aktivne dugoročne politike obuke i razvoja kadrova u tvrtki,

b. Konkretnih operativnih planova i organizacije za kvalitetnu realizaciju same obuke.

Pri projektiranju primjerenog sustava obuke uputno je koristiti provjerene sustavne modele/pristupe (Torrington, Hall i Taylor, 2004., Buble 2006.), a jedan od modela sustavnog pristupa organizacijskoj obuci (obrazovanju i razvoju) prikazan je na slici 3.

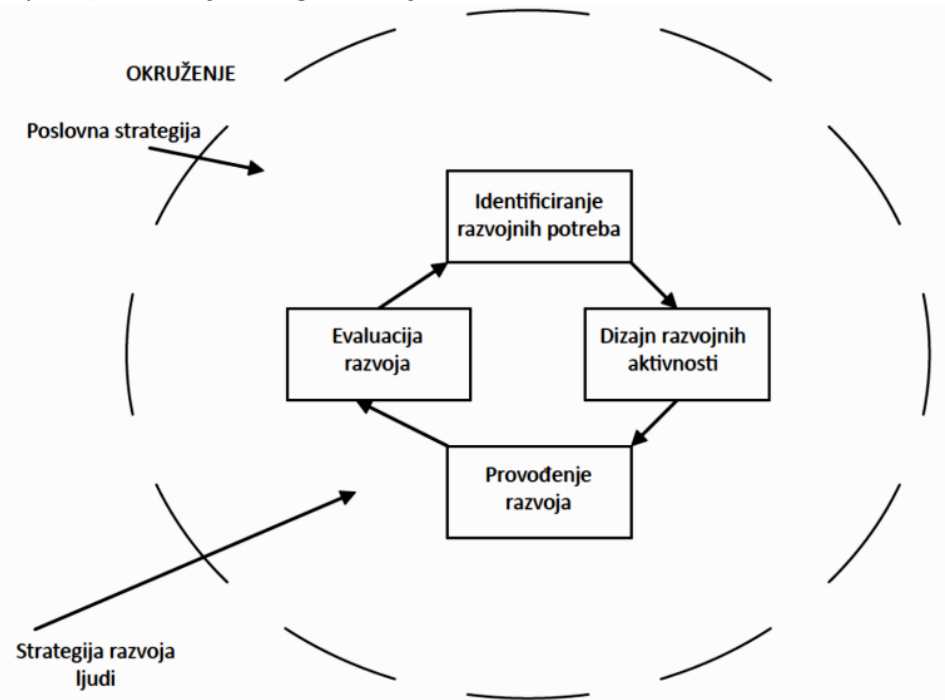

Slika 3. Sustavni pristup obuci prema modelu Torringtona, Halla i Taylora

Izvor: Torrington, Hall i Taylor (2004, str. 427)

Unutarnji dio modela sugerira četiri međusobno povezana elementa koji su u odnosu sa elementima iz kojih se taj sustav izvodi, a to su okruženje, poslovna strategija, strategija razvoja ljudskih resursa/kadrova. Naime, na temelju informacija iz okruženja tvrtke definira se poslovna strategija, iz poslovne strategije definira se strategija razvoja ljudskih resursa. Iz strategije ljudskih resursa izvodi se strategija obuke/obrazovanja/razvoja, a iz potonje elementi sustavnog modela obuke. Sustavni model obuke treba biti izgrađen na temelju međusobno povezanih elemenata (iako nisu direktno vidljivi u procesnim modelima obuke oni su imanentni svakom trenažnom procesu): 
1. Identificiranje razvojnih potreba tj. potreba za obukom (Što bi trebalo obučiti?, Koja znanja i vještine treba obučiti?);

2. Dizajna razvojnih aktivnosti tj. planiranja potrebne obuke (Što se obukom želi postići?, Kako se to treba postići?, Kada se treba postići?, Tko treba obučavati? i Gdje će se obučavati?);

3. Provođenja (i razvoja) tj. izvođenja i unaprjeđenja obuke (Koji program obuke? Koje metode obuke?);

4. Evaluacije (i razvoja) izvršene obuke (Što se obukom htjelo, a što se postiglo?).

Ovakav sustavni pristup obuci adaptira se uz upotrebu procesnog menadžmenta u rješavanju problema unaprjeđenja procesa obuke na primjeru /slučaju konkretne proizvodne tvrtke.

2 PROIZVODNA TVRTKA CAREL ADRIATIC D.O.O. I ORGANIZACIJA PROCESA OBUKE PROIZVODNIH DJELATNIKA/OPERATERA

Objekt istraživanja u ovom radu je tvrtka Carel Adriatic d.o.o. u Labinu, Hrvatska. Tvrtka je osnovana 1973. godine u Padovi, Italija, a bavi se proizvodnjom elektroničkih proizvoda i instrumenata koji se koriste pri ugradnji i kontroli sistema za klimatizaciju, grijanje i hlađenje (Biočić, 2019.; Carel Industries Spa, 2020.).

Tvrtka posjeduje pogone u Italiji, Kini, Brazilu i Sjedinjenim Američkim Državama, a od 2015. i u Hrvatskoj. Ukupno ima 23 podružnice i devet proizvodnih postrojenja te više od 1700 zaposlenika diljem svijeta od čega više od $150 \mathrm{u}$ Hrvatskoj (Biočić, 2019.; Carel Industries Spa, 2020.).

Za tvrtku proces obuke i obrazovanja spada $u$ ključne aktivnosti menadžmenta ljudskih resursa jer je cilj da djelatnici što prije postanu djelotvorni tj. da postižu visoke razine produktivnosti $i$ kvalitete.

Trenutni trenažni proces obuke za proizvodne djelatnike u poduzeću Carel Adriatic d.o.o. izgleda ovako: Nakon zapošljavanja novog operatera, početak obuke operatera započinje $s$ njegovim prvim radnim danom (orijentacija/uvođenje $u$ posao). Operater sa svojim treningom započinje na trening liniji. $\mathrm{Na}$ trening liniji obavlja četiri treninga:

- Standardi kvalitete (razumijevanje pojmova škart i defekt te način njihovog praćenja na liniji, razumijevanje standarda i uputstva za pravilan rad na liniji);

- Osnove elektronike (prepoznavanje materijala, funkcija korištenih komponenata, prepoznavanje komponenata na shemama, pravilno rukovanje komponentama);

- PTH (engl. acr. "Plated Through Hole“) trening (ručno montiranje komponenata na tiskane pločice uz pomoć shema);

- „Reworking“ trening (popravak oštećenih komponenata i tiskanih pločica prema standardu za popravak).

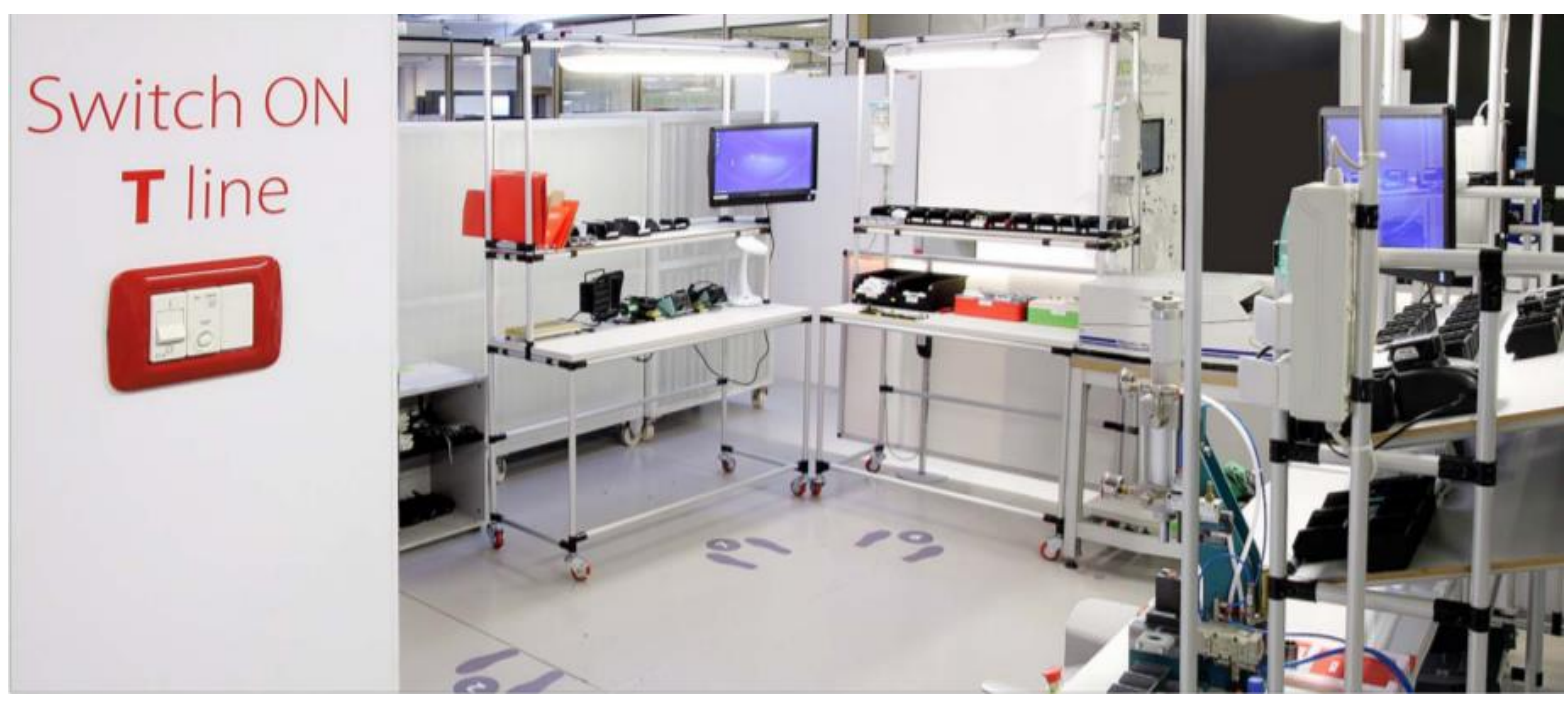

Slika 4. Trening linija Carel Adriatic d.o.o.

Izvor: Baćac, D. (2020.) Ijubaznošću menadžmenta tvrtke Carel Adriatic d.o.o., Labin. 
Trajanje treninga jest 3 dana. Na slici 4. prikazan je izgled trening linije Carel Adriatic d.o.o u Labinu.

Nakon treninga na trening liniji novi operater odlazi na proizvodnu liniju i s voditeljem linije odrađuje preostale treninge. Kako bi se novi operater mogao identificirati operater nosi oznaku: novi operater (crvena oznaka na rukavu novog operatera „OJT“ tj. engl. acr. „On the job training").

Preostali treninzi koje operater mora odraditi na proizvodnoj liniji jesu:

- Uporaba ESD (engl. „Electrostatic discharge“) opreme, priprema linije i montiranje komponenata na proizvod $u$ trajanju od 4 tjedna;

- Označavanje i pakiranje proizvoda u trajanju od 6 tjedana;

- Zamjena komponenata, testiranje i prepoznavanje pogrešaka na testu u trajanju od 5 tjedana.

Nakon završetka trećeg treninga operateru se uklanja oznaka novi operater („OJT“) te se ispunjava dokumentacija o završenom treningu novog operatera čime je proces obuke završen.

Postojeći proces obuke grafički se može prikazati grafičkim jezikom BPMN što je učinjeno na slici 5 .

Govoreći o postojećem modelu s pozicije iskustva rada u trenažnom procesu može se eksplicirati da svaki proces, pa tako i postojeći model obuke ima svoje prednosti i nedostatke. Prednost ovako definiranog procesa jest što se početak obuke ne obavlja na samoj proizvodnoj liniji već na takozvanoj trening liniji. Tako operater može unaprjeđivati svoje znanje na komadima koji ne idu kupcima. Sljedeća prednost ovog procesa jest ta što je novi operater praćen sa oznakom (crvenim slovima napisana oznaka na rukavu "OJT"), stoga ako se kraj njega nalazi iskusni operater jednostavno je provjeriti sve komade izrađene od strane novog operatera.

Nedostatak ovog procesa jest što se nakon obuke ne može utvrditi je li operater stvarno stekao neophodno znanje ili treba ponoviti obuku stoga je $\mathrm{u}$ tom dijelu potrebno poboljšati proces. Također u tvrtki od preko 150 ljudi teško je pratiti vrijeme provedeno na obuci te datume provjere znanja operatera.

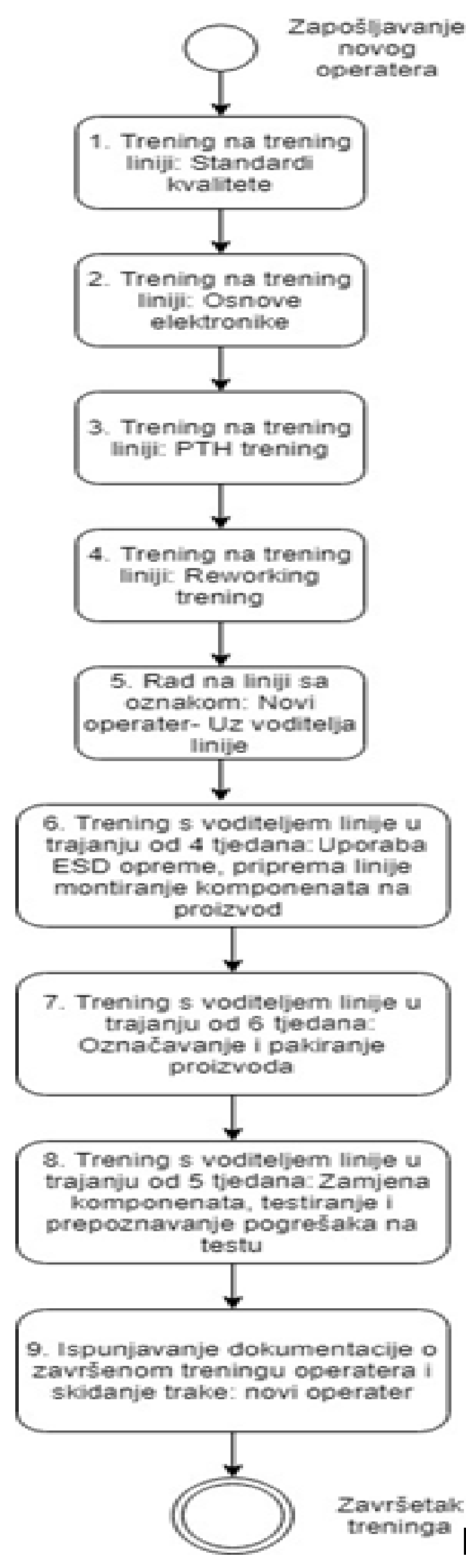

Slika 5. Proces obuke operatera prije unaprjeđenja

Izvor: Baćac, D. (2020.) 
3 ISTRAŽIVANJE PROCESA OBUKE U TVRTKI CAREL ADRIATIC D.O.O.

Ovaj rad koristi standardnu metodologiju procesnog menadžmenta s fazama:

a. identifikacija/modeliranje postojećeg procesa;

b. analiza postojećeg procesa;

c. preoblikovanje postojećeg procesa,

d. kontrola i nadzor procesa, te u okviru ovih procesnih faza istražuje nekoliko istraživačkih problema.

U prvoj fazi (IDENTIFIKACIJA I MODELIRANJE) identificiran/modeliran je postojeći proces obuke koji tvrtka trenutno provodi. Procesni model obuke onakav kakav se u tvrtci provodi prikazan slikom 5. Za njega se već na osnovu iskustva dosadašnjeg funkcioniranja može uočiti da ima nedostataka (suboptimalan je) i da su poboljšanja moguća. Naime iskustveno se utvrdilo da zaposlenici nisu dovoljno osposobljeni za rad na proizvodnoj liniji neposredno nakon obuke, da nema dovoljno kontrole u obučavanju zaposlenika (neki zaposlenici su bili predugo u obuci, neki prekratko, sami ispitivači zbog većeg broja obučavanih novih operatera nisu sigurni kad točno treba provoditi ispite, da je završni ispit kod pojedinih radnika nedovoljan u smislu provjere potrebnih znanja i vještina). Mogući simptom suboptimalne obuke i procesnog modela obuke potvrdile su i objektivne mjere reklamacije kupaca, koje također valja uzeti u obzir kao analitički važan podatak u kontekstu potrebe unaprjeđenja trenažnog procesa.

U drugoj fazi (ANALIZA)-da bi se dobila i objektivnija mjera funkcioniranja postojećeg modela izrađena je i provedena anketa s ciljnim pitanjima kako bi se utvrdilo da li su ispitanici (operateri na liniji neposredno nakon trenažnog procesa) osposobljeni i zadovoljni postojećim modelom obuke. Dodatno su neformalnim razgovorima, te logičkom analizom pojedinih faza obuke prema sustavnom pristupu obuci utvrđene "slabe karike“ u procesu obuke koje se mogu svesti na nedovoljno kvalitetnu provjeru znanja i vještina na svakoj od 4 osnovna elementa obuke koji su ključni za budućeg djelotvornog radnika na proizvodnoj liniji.

U trećoj fazi (PREOBLIKOVANJE PROCESA) postojeći proces obuke je preoblikovan sukladno rezultatima ankete i uočenim slabim karikama $u$ samom procesu upotrebom BPMN grafičkog jezika.

U zadnjoj četvrtoj fazi (NADZOR i KONTROLA) sugerirane su mjere za provedbu, nadzor $i$ kontrolu novog modela obuke. Pritom su uzeti u obzir prednosti i nedostaci novog modela obuke. Kao prednosti mogu se navesti bolja obučenost zaposlenika, brže postizanje pune djelotvornosti, veća sigurnost i zadovoljstvo zaposlenika nakon obuke, a nedostaci su: složeniji i zato nešto skuplji sustav u terminima radnog vremena i socijalnih ulaganja (više posla za ispitivače i radnike na ispitima). Budući da novi model još nije testiran tek treba utvrditi nove razine reklamacija, škarta, otpada i brzine zaposlenika nakon obuke prema novom procesnom modelu.

Hipoteza je da će se novim procesnim modelom obuke reklamacije kupaca smanjiti, brzina (produktivnost) uvećati, a škart zaposlenika smanjiti u usporedbi sa starim procesnim modelom.

Istraživački problemi inicirani su radnim iskustvom jednog od autora na trenažnoj liniji, tako da postavljeni istraživački problemi imaju karakter akcijskog istraživanja, jer su izraz uočenih problema u stvarnoj organizacijskoj praksi, konkretnije trenažnom procesu novih zaposlenika u proizvodnom pogonu tvrtke. Kod akcijskog istraživanja glavna su pitanja: a) Kakva je sadašnja situacija? i b) Što se treba/može napraviti?, a samo istraživanje ima cirkularni tijek: Istraživanje - Akcija - Evaluacija - Istraživanje (ciklus se ponavlja) (Burnes, 2004.). U kontekstu takvog istraživačkog modaliteta postavljeni su istraživački problemi:

1. Kakva je obučenost i zadovoljstvo zaposlenika postojećim procesom obuke $u$ tvrtki?

2. Kako treba preoblikovati proces obuke da se otklone uočeni nedostaci (nedovoljne obučenosti i nezadovoljstva treniranih zaposlenika)?

3. Kako povećati vjerojatnost da preoblikovani (novi) proces obuke rezultira boljim rezultatima / djelotvornošću od starog?

Sukladno uočenim i postavljenim istraživačkim problemima postavljene su i istraživačke hipoteze: 
$\mathrm{H}_{1}$ - Razina reklamacija kupaca, obučenost i zadovoljstvo zaposlenika nakon trenažnog procesa i nije dovoljno dobra/suboptimalna je.

$\mathrm{H}_{2}$ - Proces obuke treba preoblikovati sukladno sustavnom pristupu obuci $s$ naglaskom na evaluativnu komponentu tako da radnici prije angažiranja na proizvodnoj liniji prođu više manjih ispita (npr. četiri) kako bi se znanja i vještine bolje utvrdila, umjesto jednog usmenog ispita kako to sugerira aktualni proces obuke.

$\mathrm{H}_{3}-$ Vjerojatnost boljih rezultata novog procesa obuke moguće je postići pridržavanjem sustavnog pristupa obuci, napose uvođenjem novog sustava evidencije, evaluacije i kontrole, čime će čitav proces obuke dobiti na ozbiljnosti / važnosti što će najvjerojatnije rezultirati boljim učincima od prethodnog procesnog modela obuke. Povećati vjerojatnost uspješnosti novog procesnog modela obuke moguće je putem sustava nadzora, kontrole i evaluacije obuke „ad hoc“ $\mathrm{i}$ nakon toga realnim testiranjem procesnog modela "ex ante" $\mathrm{i}$ usporedbom s rezultatima starog procesnog modela. Za empirijsku potvrdu ove hipoteze procesni model je potrebno testirati $\mathrm{i}$ usporediti ga sa starim procesom obuke što je moguće tek naknadno kada novi proces obuke zaživi u praksi (,post facto") i stvarno se utvrde njegove karakteristike. Također treba imati na umu i to da i onda kada je novi proces po svojim karakteristikama bolji/napredniji od starog, teško (malo vjerojatno) je da je postignut procesni optimum pa će ga vjerojatno trebati ponovno preoblikovati (tzv. cirkularnost u metodologiji akcijskog istraživanja). Valja također uočiti da je priroda procesnih modela iterativna tj. da se do optimuma (ili do dovoljno dobrog procesnog modela) u poslovnoj praksi dolazi kroz više iteracija što je karakteristika filozofije koja teži izvrsnosti i stalnom unaprjeđenju (jap. kaizen).

\subsection{Metodologija istraživanja}

Istraživanje prvog istraživačkog problema za dobivanje uvida u osposobljenost i zadovoljstvo procesom obuke osim iskustveno i sekundarnim mjerama (analizom reklamacija kupaca) provedeno je anketnim upitnikom; drugog istraživačkog problema uvažavanjem sustavnog pristupa obuci, evaluativne komponente napose te primjenom BPMN alata i logičkog promišljanja i modeliranja kako bi se otklonile slabosti prethodnog procesnog modela obuke; a trećeg istraživačkog problema osmišljavanjem potrebnih mehanizama evidencije, evaluacije, nadzora i kontrole kako bi novi proces obuke imao visoku vjerojatnost uspješnosti „ex ante" u odnosu na aktualni procesni model.

\subsection{Istraživački instrumenti}

Kao mjera kojom se djelomično može objasniti suboptimalna kvaliteta obuke i potreba za preoblikovanjem procesa obuke korišteno je brojanje reklamacija kupaca po mjesecima gdje su uočena odstupanja od plana (ciljnih vrijednosti i veličina). Podatci $s$ grafikonom predstavljaju povjerljive informacije i interni dokument, stoga se ovdje ne prikazuju.

Stavovi zaposlenika s trenažne linije tvrtke Carel Adriatic d.o.o. istraženi su putem anketnog upitnika. Upitnik za ispitivanje primjerenosti zatečenog procesa obuke u poduzeću Carel Adriatic d.o.o. sastojao se od pet pitanja:

a. Prvo pitanje bilo je usmjereno na saznavanje informacija o prethodnom iskustvu rada $\mathrm{s}$ elektroničkim komponentama. Željelo se utvrditi da li je svim budućim djelatnicima potrebna ista razina obuke ili postoje zaposlenici koji su već velikim dijelom osposobljeni pa im je ovakva obuka neprimjerena, a možda su bili obučavani na neprimjereni način pa je za navedene zaposlenike potrebna i dodatna obuka $\mathrm{s}$ ciljem tzv. odučavanja.

b. Drugo pitanje bilo je usmjereno na dobivanje odgovora na pitanja uspješnosti obavljene obuke s subjektivnog gledišta tj. osjećaja da li mogu samostalno obavljati zadatke na radnom mjestu koji su bili predmetom trenažnog procesa.

c. Treće pitanje tražilo je odgovor na pitanje o doživljenoj kvaliteti obuke $\mathrm{i}$ jasnoći ishoda obuke (onoga što se očekuje da se obukom treba internalizirati).

d. Četvrtim pitanjem tražio se odgovor na pitanje da li je prolaz na jednom usmenom ispitu dostatan dokaz da je zaposlenik spreman za samostalan rad na proizvodnoj liniji ili nije.

e. S obzirom na činjenicu da su svi ispitivani radnici prethodno radili $\mathrm{i}$ imali trenažnog 
iskustva u ostalim tvrtkama, radi komparacije kvalitete obuke s drugim tvrtkama željelo se doznati koliko je tvrtka Carel Adriatic d.o.o. u tom smislu kompetitivna, odnosno ostvaruje konkurentsku prednost u obrazovnom procesu nad drugim tvrtkama.

\subsection{Ispitanici u istraživanju}

Za potrebe istraživanja prvog problema korišteni su svi djelatnici koji su u jednoj vremenskoj točci (razdoblju) bili u trenažnom procesu njih $\mathrm{N}=10$. Struktura uzorka prikazana je tablicom 1.

Tablica 1. Uzorak ispitanika prema podgrupama

\begin{tabular}{|l|c|c|}
\hline Podgrupe ispitanika & Broj ispitanika & Postotak (\%) \\
\hline Spol & 10 & 100 \\
Ženski & 8 & 80 \\
Muški & 2 & 20 \\
\hline Dob & 10 & 100 \\
$18-25$ & 1 & 10 \\
$26-45$ & 8 & 80 \\
$>46$ & 1 & 10 \\
\hline Radni staž u tvrtki Carel & 10 & 100 \\
$<1$ godine & 1 & 10 \\
1-5 godina & 9 & 90 \\
\hline \multicolumn{2}{|c|}{ Izvor: Rezultati istraživanja. }
\end{tabular}

$\mathrm{U}$ provedenom istraživanju dominantni su bili ispitanici (operateri u treningu) ženskog spola $(80 \%)$, dobne skupine od $26-45$ godina života $(80 \%)$ s ranim stažem od $1-5$ godina $(90 \%)$.

\subsection{Postupak istraživanja}

Primijenjen je postupak metodologije procesnog menadžmenta i to na način da je: a) najprije prikazan identificiran i modeliran postojeći poslovni proces obuke, zatim b) analiziran postojeći proces, nakon toga je c) prikazan preoblikovani proces te je na kraju, d) sugeriran način za nadzor i kontrolu novog procesa.

U prvoj fazi istraživanja (Analiza postojećeg procesa) nakon što je iskustvenom mjerom utvrđeno da postoje procesni problemi u postojećem modelu obuke (naročito u dijelu kontrole i evaluacije naučenih vještina), mjere reklamacija iznad planskih veličina (koje se barem djelomično mogu pripisati sustavu i procesu obuke) pristupilo se dodatnom ispitivanju zaposlenika glede njihova mišljenja o procesu obuke, obučenosti i zadovoljstva istim kako bi se dobila cjelovita slika o kvaliteti postojećeg procesa obuke i potrebi za njegovim unaprjeđenjem. Anketirani su novi operateri (radnici) neposredno nakon završetka obuke upitnikom tipa papirolovka. Proces je preoblikovan u 2. fazi upotrebom alata BPMN i logike procesnog modeliranja obuke koji se temelji na iskustvu autora u obuci operatera. U trećoj fazi (Nadzor i kontrola) navedene su nove mjere nadzora i kontrole koje su potrebne kako bi novi procesni model imao poboljšan procesni tijek i kvalitetu.

\section{REZULTATI I DISKUSIJA ISTRAŽIVANJA}

Preliminarna analiza kritičnih problema tvrtke utvrdila je da je broj reklamacija kupaca na proizvode tvrtke bio kritičan (nezadovoljavajući s obzirom na željenu vrijednost) u razdoblju od ožujka-srpnja 2020. Osim mogućih uzroka ovog fenomena kao što su: zamor zaposlenika na proizvodnoj liniji, lošiji objektivni uvjeta rada, nemotiviranost, mogući uzrok povećanim reklamacijama u razdoblju ožujak-srpanj 2020. može se dijelom pripisati i ubrzanom procesu obuke koji je proizvodio suboptimalne rezultate $u$ proizvodnom pogonu. $U$ razdoblju od 5 mjeseci u tvrtki je bilo zaposleno više od 30 novih operatera, pa se može očekivati da će trend broja reklamacija rasti ukoliko se proces obuke novih operatera ne unaprijedi.

Rezultati istraživanja prikazani su sukladno postavljenim problemima i hipotezama istraživanja. 


\subsection{Rezultati i diskusija glede} analize postojećeg modela obuke u kontekstu obučenosti i zadovoljstva trenažnim procesom

Rezultati provedenog istraživanja stavova zaposlenika u pogledu kvalitete i zadovoljstva trenažnim procesom prikazani su slikom 6 .

Dobiveni rezultati ukazuju na zaključak o suboptimalnostima trenažnog procesa. Konkretno:

a. Na prvo pitanje: „Jeste li imali prijašnjih iskustava u radu sa elektroničkim komponentama?" devet zaposlenika je odgovorilo „nimalo“, a jedan „između 1 i 5 godina“. To znači da je obuka vrlo bitna karika proizvodnog procesa s obzirom na to da je većina operatera bez iskustva u radu $s$ elektroničkim komponentama.

b. Slijedeće pitanje u upitniku bilo je: „Jeste li se nakon obavljene obuke osjećali da možete samostalno obavljati zadatke koji se očekuju od Vas?" Od deset zaposlenika tri je odgovorilo "Nimalo", šest zaposlenika „Umjereno“, dok je samo jedan zaposlenik rekao da se u potpunosti osjećao da je samostalan za rad. Iz toga se može zaključiti da su radnici radili na proizvodnoj liniji samostalno, a ni sami nisu imali osjećaj da su sposobni za samostalan rad.

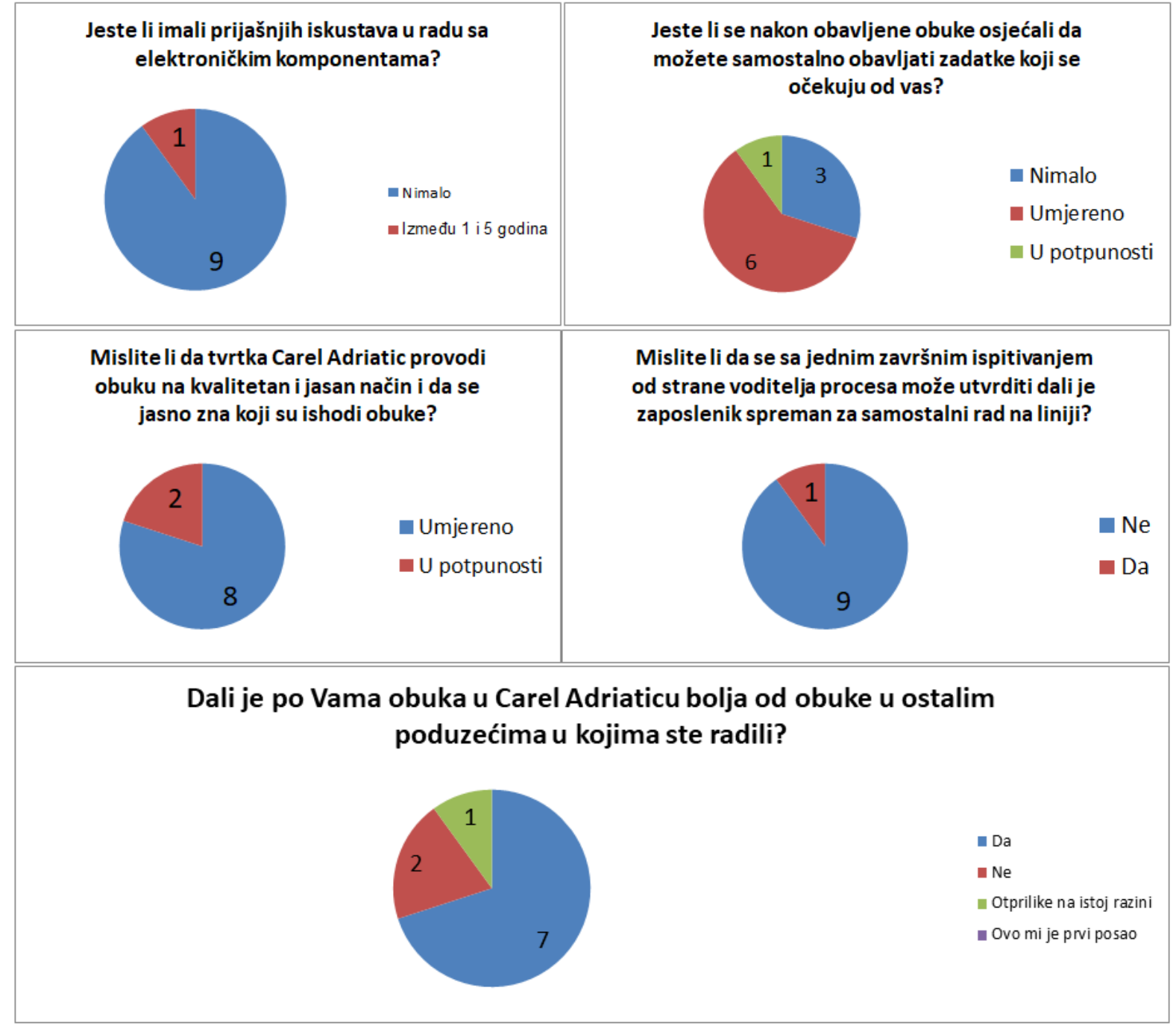

Slika 6. Rezultati anketnog upitnika

Izvor: Rezultati istraživanja.

c. Na pitanje „Mislite li da tvrtka Carel Adriatic provodi obuku na kvalitetan i jasan način i da se jasno zna koji su ishodi obuke?" osam je zaposlenika odgovorilo „Umjereno“, a dva „U potpunosti“. S tim rezultatom odgovora moguće je zaključiti da je svakako potrebno 
unaprijediti sadašnje stanje obuke kako bi sami zaposlenici jasno razumjeli koji su ishodi obuke i što se zapravo očekuje od njih. Ukoliko ni sami zaposlenici nisu sigurni što se zahtijeva od njih ne može se reći da se obuka održava na dovoljno kvalitetan način.

d. Na pitanje: "Mislite li da se sa jednim završnim ispitivanjem od strane voditelja procesa može utvrditi da li je zaposlenik spreman za samostalni rad na liniji?" devet je osoba odgovorilo „Ne“, a samo je jedna osoba odgovorila "Da“ iz čega se može zaključiti da većina zaposlenika $(90 \%)$ misli da ovakav način ispitivanja znanja operatera za samostalni rad na liniji nije dobar i da ga je potrebno unaprijediti. Iz ovog rezultata za zaključiti je kako je proces obuke zaposlenika potrebno unaprijediti i da ni sami zaposlenici nemaju osjećaj da je trenutni proces kvalitetan, stoga su nužni prijedlozi za poboljšanje.

e. Posljednje pitanje u upitniku bilo je „Da li je po Vama obuka u Carel Adriaticu bolja od obuke u ostalim tvrtkama u kojima ste radili?". Sedam je osoba odgovorilo da je, po njima, bolja obuka u Carel Adriaticu od prijašnjih tvrtki u kojima su radili. Dvije su osobe odgovorile da je u prijašnjim tvrtkama u kojima su radili bila bolje organizirana obuka, dok je jedan ispitanik odgovorio da je obuka otprilike na istoj razini kao i u drugim tvrtkama u kojima su radili. Iz ovih odgovora moguće je zaključiti da ni ostale tvrtke u bližem okruženju ne posvećuju veliku pažnju obuci. Međutim, ukoliko tvrtka Carel Adriatic želi i dalje biti konkurentna na međunarodnom tržištu treba permanentno unaprjeđivati proces obuke kako bi se osiguralo da radnici imaju znanja i vještine kojima bi se osigurala kvaliteta usluga koje tvrtka Carel Adriatic pruža svojim kupcima. Ovim rezultatima potvrđena je prva hipoteza istraživanja.

Slika 7. Proces obuke nakon poboljšanja Izvor: Rezultati istraživanja.

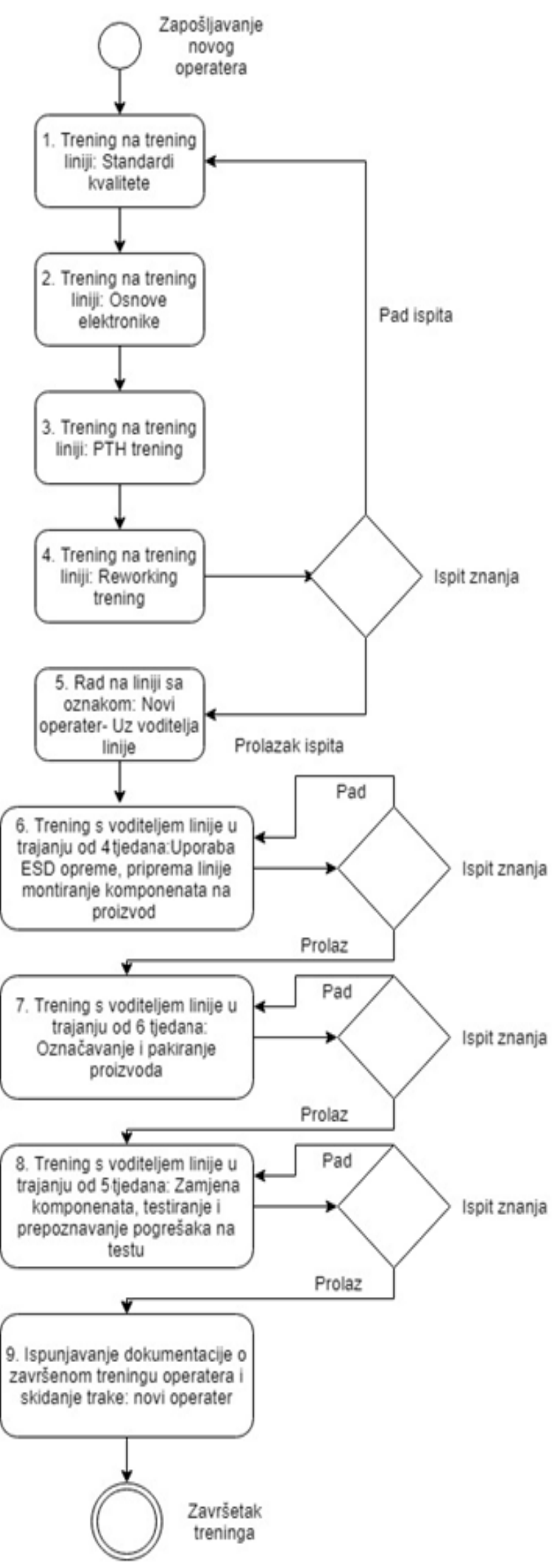




\subsection{Rezultati i diskusija glede preoblikovanja i poboljšanja procesa obuke}

Nakon što su se definirali nedostatci procesa potrebno je osmisliti rješenja. Iz samog upitnika je vidljivo kako se većina operatera ne osjeća sigurno za samostalan rad nakon obavljenog treninga pa je navedeni nalaz važan razlog za preoblikovanje procesa obuke u kontekstu njegovog unaprjeđenja. Rješenje za utvrđivanje znanja jest provjera znanja nakon svakog treninga. Sugerira se pismeni ispit pa će operater moći imati uvid u pogreške. Ukoliko operater nije prošao provjeru znanja polazi trening ispočetka. Provjere znanja u poboljšanom procesu bile bi: a) Ispit nakon treninga na trening liniji; b) Ispit nakon svakog od tri treninga obavljenog sa voditeljem linije na samoj proizvodnoj liniji. Unaprjeđeni model prezentiran je na slici 7 .

Modeliranjem novog procesa obuke potvrđena je druga hipoteza istraživanja.

\subsection{Rezultati i diskusija glede unaprjeđenje sustava nadzora i kontrole procesa obuke}

Poslovne strategije i operativni planovi koji su sve do kraja 80 -ih godina prošlog stoljeća u čak $90 \%$ tnoj stopi bili neuspješni u dostizanju organizacijskih ciljeva bili su neuspješni upravo iz razloga nemogućnosti teorije menadžmenta da odgovori na izazov sustavne kontrole organizacijskog sustav i procesa (https://holspico.hr/sustav-mjerenja-ucinkovitosti, 20. 04. 2020.). Iz navedenog razloga sugerira se pojačana sustavna kontrola obuke koja u ispitnom procesu implementira četiri ispitne provjere (Slika 8.).

Prema novom procesnom modelu obuke nakon svakog ispita novi zaposlenici će ispuniti formular u kojem će ocijeniti kvalitetu obuke i dati prijedloge za njeno unaprjeđenje. Tako će se omogućiti stalno unaprjeđenje trenažnog procesa koji će biti usklađen sa svim fazama sustavnog pristupa obuci gdje je nadzor i kontrola procesnog modela ulazna i izlazna varijabla. Ulazna u smislu pokretanja novih poboljšanih procesa, a izlazna u smislu provjere da li se i u kolikoj mjeri postojeći proces obuke radi na ispravan način (engl. doing the process right) i da li se uopće radi/provodi pravi proces (engl. doing the right process).

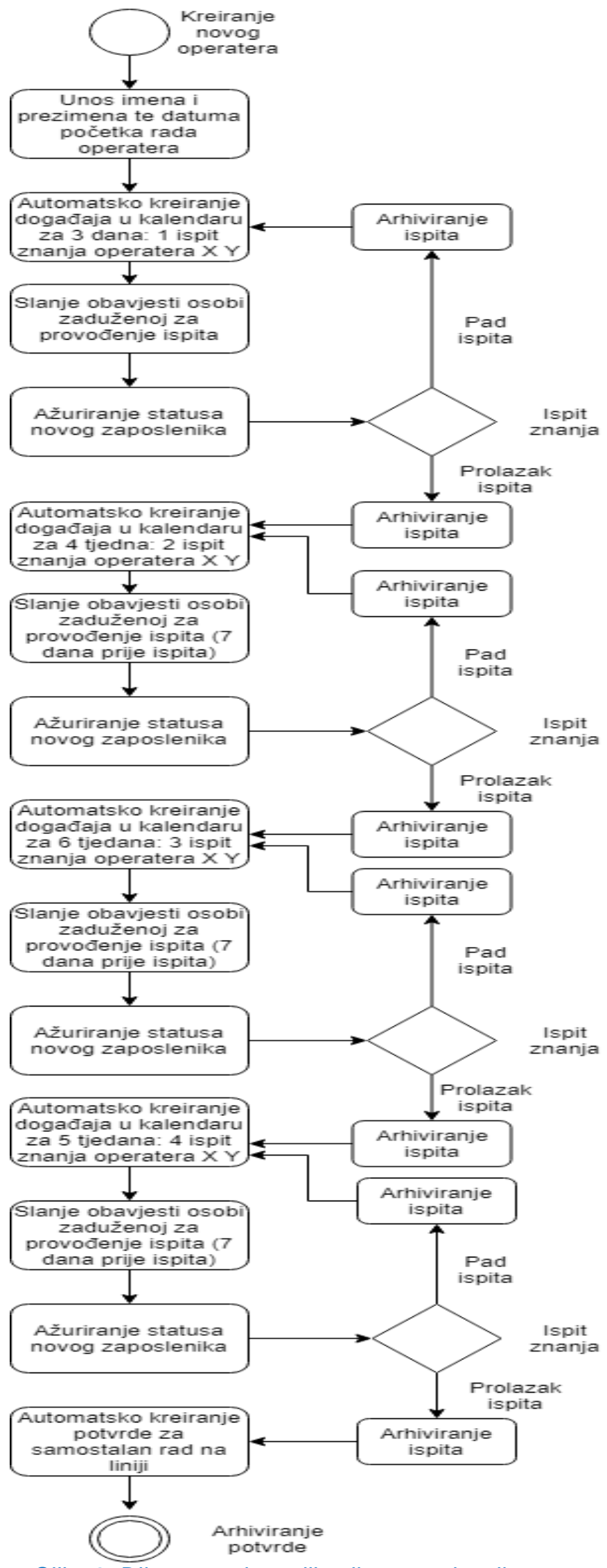

Slika 8. Dijagram toka aplikacije za evaluaciju znanja operatera

Izvor: Rezultati istraživanja. 
U kontekstu osiguranja uspješnosti novog procesnog modela obuke javlja se nekoliko operativnih problema koji se mogu izvesti iz sustavnog pristupa obuci:

a. Problem detaljnog planiranja potrebne obuke (osim samog procesnog modela) svaku fazu obuke treba detaljno isplanirati u smislu točnih željenih ishoda obuke, načina provedbe, vremena potrebnog za ostvarivanje željenih ishoda obuke, obuke edukatora i prostora za obuku. (Rješenje: operativna standardizacija procesa obuke).

b. Problematika programa obučavanja (da li je program primjeren stvarnim potrebama?) i korištene metode obuke (treba izabrati između brojnih metoda koje su teorijski podijeljene na: metode obuke na poslu metode obuke izvan posla). (Rješenje: odabrati program usmjeren na uspješnost na poslu i koristiti standardne metode poučavanja visoke razine učinkovitosti).

c. Problem evaluacije izvršene obuke tj. praćenja novih operatera te raspored provjera znanja. (Rješenje: potrebno je osmisliti alat za praćenje rada novih operatera i praćenje provjera znanja/vještina svakog operatera).

Na kraju kako bi se stvarno utvrdilo koliko je novi preoblikovani proces zapravo dobar i da li daje dobre rezultate potrebno je mjeriti učinkovitost procesa obuke. Pritom se mogu evaluirati:

- Resursi korišteni u procesu obuke (materijalni troškovi i potrebna socijalna ulaganja),

- Reakcije sudionika nakon završene obuke (pisanim anketnim upitnikom ili usmeno),

- Mjerenje naučenog (npr. ispitom nakon obuke),

- Mjerenje performansi (npr. kvantiteta, kvaliteta) i ponašanja polaznika na poslu poslije obuke (pridržavanje propisanih mjera, npr. zaštite na radu),

- Mjerenje/evidentiranje posljedica obuke na tvrtku (pozitivne, neutralne i/lil negativne posljedice novog procesnog modela obuke),

- Mjerenje/evidentiranje neekonomskih (socijalnih) korisnosti kao posljedica obuke.

\section{ZAKLJUČAK}

Upravljanje poslovnim procesima je važno jer pomaže u poboljšavanju cjelokupnog poslovanja.
To umanjuje rashode tvrtke, pruža bolju kontrolu načina rada, precizira operativne nedostatke $i$ daje uvid u donošenje boljih poslovnih odluka te precizno prilagođava procese za povećanje fleksibilnosti tvrtke. Jedna od najočitijih prednosti upravljanja poslovnim procesima je povećana produktivnost i kvaliteta. To poslovnim organizacijama omogućuje pojednostavljenje poslovnih procesa uklanjanjem suvišnih ili neučinkovitih zadataka kao i automatizaciju bilo kakvih najmanjih poslova. Također učinkoviti procesi dovode do boljih učinaka (to jest, bolje kvalitete proizvoda, brži rad i sl.) jer se zaposlenici usredotočuju na temeljne funkcije.

$U$ ovom radu upotrebom faza procesnog menadžmenta identificirao se i modelirao postojeći proces obuke. Zatim se analizirao postojeći proces obuke temeljem iskustvene metode navođenjem prednosti i nedostataka starog modela, uočavanja visokog broja reklamacija i anketnim ispitivanjem desetorice operatera. Rezultati anketnog upitnika pokazali su kako se većina operatera nakon obavljene obuke ne osjeća sposobno za samostalan rad te da je proces potrebno poboljšati. Stoga su u radu osmišljena rješenja za poboljšanje kojima će se unaprijediti kvaliteta obuke te olakšati praćenje operatera na obuci. Također je definiran i način nadzora i kontrole novog procesa, osim obuke uz pomoć ispita nakon svakog djela obuke pomoću sadržaja elemenata sustavnog pristupa obuci.

Potvrđene sve tri istraživačke hipoteze iz kojih se mogu eksplicirati specifični i široko primjenjivi doprinosi u modeliranju procesa obuke:

1. Proces obuke moguće je identificirati, analizirati i utvrditi njihove nedostatke (suboptimalnosti). U tu svrhu korisno je primijeniti procesni menadžment $\mathrm{i}$ sustavni pristup obuci.

2. Proces obuke moguće je preoblikovati i unaprijediti slabe točke procesa.

3. Za svaki proces obuke moguće je ponuditi operativnu potporu (potporne elemente) koji se mogu izvesti iz sustavnog pristupa obuci.

Na ovakav sustavan način primijenjena su znanja procesnog menadžmenta i sustavnog pristupa obuci pri unaprjeđenju procesa obuke, a u funkciji poslovne djelotvornosti i izvrsnosti. 


\section{CITIRANA DELA}

Baćac, D. (2020.). Procesni pristup obuci u proizvodnoj organizaciji Carel Adriatic d.o.o., završni rad na specijalističkom diplomskom stručnom studiju. Pula: Istarsko veleučilište-Universita Istriana di science applicate.

Bahtijarević-Šiber, F. (1999). Management ljudskih potencijala. Zagreb: Golden Marketing.

Biočić, B. (2019). Labinska tvrtka Carel Adriatic bavi se tehnologijom klimatizacije: Puno ulažu u mlade zaposlenike. Dostupno na: https://www.glasistre.hr/istra/labinska-tvrtka-carel-adriatic-bavi-setehnologijom-klimatizacije-puno-ulazu-u-mlade-zaposlenike-612058 (pregledano: 24. 04. 2020.).

Bogdanović, M., Durian, J., \& Cingula, D. (2016). HRM Choices for Business Strategy Support: How to resolve the most important HRM Strategic Dilemmas? Book of Proceedings of $15^{\text {th }}$ International Scientific Conference on Economic and Social Development - Human Resource Development, Varaždin, Croatia, 09-10. June 2016., 429-445.

Brumec, J., \& Brumec, S. (2018). Modeliranje poslovnih procesa, Zagreb: Školska knjiga.

Brumec, J. (2011). Modeliranje poslovnih procesa, Varaždin/Zagreb; Konzalting Organizacija Razvoj IS, dostupno na, https://koris.hr/preuzmi/koris-uvod-u-modeliranje-poslovnih-procesa.pdf

Buble, M. (2006). Menadžment, Split: Ekonomski fakultet u Splitu.

Burnes, B. (2004, sept). Kurt Lewin and the Planned Approach to Change: A Re-appraisal. Journal of Management Studies, 41(6), 977-1002, dostupno na https://onlinelibrary.wiley.com/doi/epdf/10.1111/j.1467-6486.2004.00463.x

Carel Industries Spa: „Carel Adriatic“, dostupno na: https://www.carel.com/carel-adriatic (pregledano: 24. 04. 2020).

Carel Industries Spa: „What we do“, dostupno na: https://www.carel.com/what-we-do (pregledano: 26. 07. 2020).

Dumas, M., La Rosa, M., Mendling, J., \& Reijers, H. A. (2013). Fundamentals of Business Process Management, Springer - Heidelberg - New York - Dordrecht - London: Springer Verlag, dostupno https://dinus.ac.id/repository/docs/ajar/Fundamentals_of_Business_Process_Management_1. pdf

Fabac, R. (2017). Dizajniranje organizacije i upravljanje promjenama-projektni pristup. Zagreb: Naklada Slap.

Holspico sustav mjerenja učinkovitosti. (2018). dostupno na: https://holspico.hr/sustav-mjerenjaucinkovitosti/ (pregledano: 20. 04. 2020).

Martinek, E. (2018). Modeliranje poslovnih procesa pomoću grafičkog jezika BPMN“, diplomski rad. Zagreb: Sveučilište u Zagrebu, Prirodoslovno-matematički fakultet, Matematički odsjek, dostupno https://repozitorij.pmf.unizg.hr/islandora/object/pmf\%3A6010/datastream/PDF/view

Nassazi, A. (2013). Effects of Training on Employee Performance: Evidence from Uganda, final thesis, Vaasa: University of Applied Sciences Vaasa, dostupno na https://core.ac.uk/download/pdf/38098025.pdf

Quible, Z. K. (2010). Menadžment uredskog poslovanja, 8. izdanje. Zagreb: Mate d. o. o. 
Rizkalla, E. (2014). Not Investing in Employee Training is Risky Business, dostupno na: https://www.huffpost.com/entry/not-investing-in-employee_b_5545222?guccounter=1 (pregledano: 28. 11. 2020).

Torrington, D., Hall, L., \& Taylor, S. (2004). Menadžment ljudskih resursa, 5. izdanje. Beograd: Datastatus.

Vukšić-Bosilj, V., Hernaus, T., \& Kovačič, A. (2008). Upravljanje poslovnim procesima. Zagreb: Školska knjiga.

Whitemore, J. (2018). Trening za postizanje učinkovitosti. Zagreb: Mate d. o. o.

Received for publication: $\quad$ 11.11.2020.

Revision received: $\quad 29.11 .2020$.

Accepted for publication: $\quad$ 05.04.2021.

Kako citirati ovaj rad? / How to cite this article?

Style - APA Sixth Edition:

Bogdanović, M., \& Baćac, D. (2021, 04 15). Procesni menadžment kao sredstvo unaprjeđenja obuke na primjeru proizvodne tvrtke. (Z. Čekerevac, Ur.) FBIM Transactions, 9(1), 12-27. doi:10.12709/fbim.09.09.01.02

Style - Chicago Sixteenth Edition:

Bogdanović, Mario, i Dino Baćac. 2021. „Procesni menadžment kao sredstvo unaprjeđenja obuke na primjeru proizvodne tvrtke." Urednik Zoran Čekerevac. FBIM Transactions (MESTE) 9 (1): 12 27. doi:10.12709/fbim.09.09.01.02.

Style - GOST Name Sort:

Bogdanović Mario i Baćac Dino Procesni menadžment kao sredstvo unaprjeđenja obuke na primjeru proizvodne tvrtke [Časopis] // FBIM Transactions / ur. Čekerevac Zoran. - Beograd: MESTE, 1504 2021. - 1 : T. 9. - str. 12-27.

Style - Harvard Anglia:

Bogdanović, M. \& Baćac, D., 2021. Procesni menadžment kao sredstvo unaprjeđenja obuke na primjeru proizvodne tvrtke. FBIM Transactions, 15 04, 9(1), pp. 12-27.

Style - ISO 690 Numerical Reference:

Procesni menadžment kao sredstvo unaprjeđenja obuke na primjeru proizvodne tvrtke. Bogdanović,

Mario i Baćac, Dino. [ur.] Zoran Čekerevac. 1, Beograd: MESTE, 1504 2021, FBIM Transactions, T. 9, str. 12-27. 